\title{
Effect of combined use of crushed sand and Algerian desert dune sand on fresh properties and strength of self-compacting concrete
}

BENCHAA BENABED - Civil Engineering Laboratory, University of Laghouat - b_benchaa@yahoo.fr

Érkezett: 2018. 06. 14. - Received: 14. 06. 2018. - https://doi.org/10.14382/epitoanyag-jsbcm.2018.29

\begin{abstract}
The main objective of this research work is to examine the influence of combined use of various types of sand on the fresh and hardened properties of SCC. The types of sand used are crushed sand (CS), river sand (RS) and dune sand (DS). In addition, binary or ternary system mixture of these sands were also used. SCC mixes were made with constant content of cement and marble powder waste. In this investigation, the flow ability was evaluated by slump flow, L-Box, J-ring V-funnel tests for SCC. The resistance to segregation was measured by GTM sieve stability test. Compressive strength was also determined at age of 28 days. The experimental results indicate that, there is an improvement in the fresh and strength properties of SCC when using binary mixtures of CS and RS. However, there is a decrease in workability and strength using binary system of CS+DS and RS+DS especially for higher DS content up to $50 \%$. This effect was also observed with SCC containing ternary system (CS+RS+DS). Based on the results obtained of this investigation, CS and DS may provide a readily available alternative material to ordinary fine aggregates in concrete applications with competitive cost.

Keywords: crushed sand, river sand, dune sand, binary system, ternary system, SCC, fresh properties, strength

Kulcsszavak: zúzott homok, folyami homok, dūne homok, kétkomponensú rendszer, háromkomponensú rendszer, öntömörödô beton, frissbeton, szilárdság
\end{abstract}

\section{Introduction}

Self-compacting concrete (SCC) is a new generation of concrete that fits well with the current state of development of the structures facing a labor less qualified. This range of concrete is characterized by a high workability and a high deformability, while being stable and ensures durable structures. For achieving these contradictory properties, the formulation of SCC needs the use of high Portland cement content and superplasticizer (SP). However, using high volume of Portland cement causes many problems such as: increase in the consumption of cement; environmental impacts due to $\mathrm{CO}_{2}$ emissions; consumption of energy and natural resources; high production cost since the cement is the most expensive element in the concrete; risk of cracking associate to the high heat of cement hydration. The SCC can be implemented without vibration, through confined areas only under the effect of gravity, while developing good compactness without requiring skilled labor during the consolidation. These properties contribute to a sustainable concrete quality. Depending on the density and complexity of the reinforcement of structural elements, the need for vibration can decrease significantly and even be eliminated, which is a labor-intensive economy [1,2]. SCC is characterized, in general, by a formulation containing various chemical and mineral additives in precise proportions to meet the requirements of the specifications for workability and stability. The incorporation of supplementary cementitious materials improves the rheological, physical, mechanical and durability properties of SCC $[3,4]$. For example, the limestone fillers are generally used to increase the amount of powder in the composition of SCC [5]. Recycling waste powders of marble and granite in the production of SCC was proved to be useful because the marble powder acts as filler, and granite powder acts as pozzolanic material despite its small pozzolanic activity [6].

The demand for natural sand is quite high in developing countries owing to rapid infrastructural growth which results supply scarcity. Therefore, construction industries of developing countries are in stress to identify alternative materials to replace the demand for natural sand. On the other hand, the advantages of utilization of by-products or aggregates obtained as waste materials are pronounced in the aspects of reduction in environmental load and waste management cost, reduction of production cost as well as enhancing the quality of concrete. Quarry dust has been used for different activities in the construction industry such as road construction and manufacture of building materials. Crushed rock aggregates are more suitable for production of high strength concrete compared to natural gravel and sand. High percentage of dust in the aggregate increases the fineness and the total surface area of aggregate particles. In the production of crushed sand, there is a significant proportion of fines in the sand; this proportion of fines is approximately $10-15 \%$ of the total weight of crushed sand. The use of sands rich in fines may be regarded as an alternative source of fillers. These sands enhance the cost of SCC by reduction of the high demand for fillers on the one hand. On the other hand obtaining a SCC with good physical and mechanical properties such as permeability, absorption and strength [7-18]. 
Attempts have been made to investigate some property of quarry dust and the suitability of those properties to enable quarry dust to be used as partial replacement material for sand in concrete $[19,20]$. The use of quarry dust in concrete is desirable because of its benefits such as useful disposal of by products, reduction of river sand consumption as well as increasing the strength parameters and increasing the workability of concrete [21, 22]. The overall workability value of quarry dust concrete in terms of slump as well as compaction factor was less in comparison to conventional concrete. The workability of the concrete mixes decreased with an increase in percentage of stone dust. It indicates that water requirement is higher in such concrete to maintain the desired workability [23-31]. Celik et al. [19] studied the effects of various proportions of crushed dust content on properties of fresh concrete and hardened concrete. Test results indicate that slump of concrete decreased as the percentage of dust content increased, and air content of fresh concrete decreased as the percentage of dust content increased. Saeed and Shahid [28] have found that workability of various mix ratios decreased from $11 \%$ to $67 \%$, whereas compressive strength increased from $7 \%$ to $33 \%$ with increasing proportion of manufactured sand. Akrout et al. [29] investigated an experimental study on the effect of crushed limestone sand proportioning to the workability and the compressive strength of concrete. The performance of the crushed limestone sand concretes was compared with those of siliceous sand concretes. It was observed that, the properties of crushed limestone sand concretes, although lower than those of siliceous sand concretes, remain completely comparable.

Shi-Cong and Chi-Sun [32] showed that the workability of crushed fine stone CFS concrete mixes was decreased with an increase in CFS content probably due to the angular shape of the CFS when compared to river sand. Also, Donza et al. [33] found that when crushed sand was incorporated in concrete, the increase of water demand due to the shape and texture of the crushed sand can be mitigated by using a water reducing admixture [34]. Rao et al. [35] reported an increasing compressive strength by use of rock flour as fine aggregate instead of river sand. The idea of using quarry sand as an alternative aggregate was developed because granite, which is the parent material, is hard and dense and therefore can serve as an excellent aggregate material. Its use as a fine aggregate in concrete is expected to improve certain properties, such as the compressive strength, durability, strength development, workability and economy. The importance of the compressive strength in concrete is such that for structural design purposes, the compressive strength is the criterion for quality.

Menadi et al. [11] showed the influence of fines in crushed sand on the physical and mechanical properties of concrete. Four different cement types were used while maintaining a constant water/cement ratio, and examined the influence of limestone fines in crushed sand on concrete strength. The test results showed that up to $15 \%$ of fines content in crushed sand could be used without adversely affecting concrete strength. It was tried experimentally to explore the use of crusher dust, stone chips and fly ash in self-compacting concrete. Test results indicated that for SCC, sufficiently low water to powder ratio can be attained even with the use of crusher dust, leading to high compressive strength [36].
Shanmugapriya and Uma [37] concluded from experimental researchers that compressive and flexural strength of concrete can be improved by partial replacement of cement by silica fume and manufactured sand for natural fine aggregates. They suggested that optimum replacement of natural sand by manufactured sand is 50\%. Raman et al. [38] studied the effect of quarry dust and found that the partial replacement of river sand with quarry dust without resulted in a reduction in the compressive strength of concrete. Reddy and Reddy [39] reported an increasing compressive strength by use of rock flour as fine aggregate instead of river sand. Ilangovana et al. [30] reported strength of quarry rock dust concrete was comparably more than that of similar mix of conventional concrete. Hameed and Sekar [31] studied effect of crushed stone dust as fine sand and found the flexural strength increases than the concrete with natural sand but the values decreases as percentage of crusher dust increases.

Ilangovana et al. [30] found that the natural river sand, if replaced by hundred percent quarry rock dust from quarries, may sometimes give equal or better than the reference concrete made with Natural Sand, in terms of compressive and flexural strength studies. Also, they concluded that the replacement of fine aggregate with 50\% marble powder and 50\% quarry rock dust gives an excellent result in tensile strength. Poon et al. [34] reported that the hardened properties of concrete mixes with partial proportions of manufactured and natural sand achieved a higher compressive strength at all test ages for normal strength, intermediate strength and high strength concrete.

In many desert regions, there is an abundance of fine sand dunes, particularly in Sahara desert of Algeria, which covers more than $60 \%$ of its area. The idea of promoting its value in the manufacturing of concrete represents a great economic importance. With the depletion of aggregate resources in Algeria and the high cost of transportation, it becomes economic and environmental interests that could present the valorization of abundant local sands such as the dune sand for manufacturing of concretes. Bederina et al. [40] have studied the possibility of using local sand available in large quantities in sandcrete. This study showed that the correction of the granular distribution by means of mixing two local sands in predetermined proportions has allowed obtaining a more workable, more compact, and more resistant sandcrete. In concrete design, the dosage and fineness of aggregates have an important influence on quality of fresh and hardened properties of concrete. Brouwers and Radix [41] have found that the fine sand is useful component in optimizing the particle size distribution and thereby increasing the flowability, stability and mechanical properties of concrete mixes. Kay et al. [42] investigated the potential of using DS as fine aggregates in concrete. Results indicated that DS could be used as fine aggregate in concrete production. Banfill et al. [43] have also studied the effect of very fine sand dredged from river estuaries on concrete mixtures. It was found that as the sand content increases, the water required for a given workability increases and the strength development is not different than conventional concrete. Laquerbe et al. [44] studied the effect of using laterite gravel and DS as aggregates for concrete. The authors showed that, the laterite gravels can be used instead of basalt or limestone, and DS can serve as a substitute for seashore sand. 
Bouziani et al. [45-49] have studied the properties of flowable concrete (FSC) made with DS. Test results show that an optimal content of dune sand, which makes satisfied fresh and hardened properties of FSC, is obtained. Bouziani [47] used a mixture design modelling approach to highlight the effects of river sand (RS), crushed sand (CS) and dune sand (DS) on flowability, passing ability, segregation and mechanical strength of SCC. The derived mathematical models make it possible to illustrate the variation of different responses in with respect to the proportions of RS, CS and DS. Results indicate that when flowability requirements are combined, proportions of DS and CS with RS must be below 0.24 and 0.6 respectively. Moreover, it is shown that passing ability can be satisfied by using a CS proportion above 0.3 in RS-CS system and above 0.65 in CS-DS system. On the other hand, proportions above 0.5 of CS in RS-CS system and above 0.2 of DS in RS-DS system are recommended to meet stability limits. Results also indicate that compressive strength days increased with the increase of CS proportion and decreased with the increase of DS proportion. Another experimental research on fresh and hardened properties of flowable sand concrete (FSC) reinforced by polypropylene fibers (PF) has been carried out by Bouziani et al. [48]. Results indicate that all studied mixtures have a pseudo-plastic behavior in fresh state. Results also confirmed that PF incorporation increases the viscosity and reduces free shrinkage of FSC. In terms of mechanical strength, results show that incorporating PF would enhance flexural strength. However, a reduction in compressive strength is observed.

R'mili et al. [50, 51] studied the incorporation of roller sand, crushed sand and desert sand in the composition the selfcompacting concretes (SCC). Desert dune sand, which has a fine extra granulometry, and the crushed sand, which contains an important content of fines, can constitute interesting components for SCC. These sands, with different sizes, consist of several combinations of rolled sand (RS), crushed sand (CS) and desert sand (DS). The study examines the influence of the granular combination of sands on the characteristics in the fresh and the hardened state of SCC. The results of the experimental tests showed an improvement of the workability of the fresh SCC by combining the different sands. The addition of the DS to CS or to RS allowed to increasing the mixture viscosity, but decreased the mechanical strengths. Furthermore, the CSRS combinations increased the compressive and the tensile strengths of the studied SCC. The optimized formulations of sands gave the highest performances of the SCC.

It should be noted that, no detailed investigation has been done to study the effect of combining different sand in binary and ternary system on some properties of self-compacting concrete. It is in this context that, the present work aims to study the effect of different types of sand fresh and hardened properties of SCC made with marble powder as cement replacement in one hand. In the other hand, recycling this waste powder, which is not used and can cause a very serious environmental problem.

In this regard, three types of sand with different origin and morphology are used; crushed sand (CS), dune sand (DS) and river sand (RS). Binary (CS+DS; CS+RS; RS+DS) and ternary $(\mathrm{CS}+\mathrm{DS}+\mathrm{RS})$ system mixtures of proportions of these sands were also used in this study. Tests used to evaluate the filling ability are slump flow and V-funnel tests. The passing ability was measured by L-Box and J-ring tests. The resistance to segregation was checked by GTM sieve stability test. Compressive strength were also determined at age of 28 days.

\section{Materials and tests}

\subsection{Materials}

The cement used in the present study was a CEM I 42.5. The chemical and physical properties of cement are given in Table 1. The waste marble powder (WMP) used in this study as cement supplementary material is a waste powder resulting from cutting, shaping and lustrating of the marble stones as shown in Fig 1. The chemical composition and physical properties of WMP are also given in Table 1. From this table, the WMP is mainly consisted of calcite about $56.01 \%$ with some traces of the quartz and dolomite as confirmed shown by of X-ray diffraction analysis presented in Fig. 2. Scanning electron microscopy (SEM) was performed to determine the surface characteristics of the WMP and typical image is presented in Fig. 3. As it can be seen, WMP presents angular shapes with rough surface texture. In order to determine particle size distribution of WMP and cement, laser distribution analysis was realized and the results are illustrated in Fig. 4. The results indicate that WMP is relatively finer than the cement, and about $70 \%$ of particles of WMP have a size less than $10 \mu \mathrm{m}$, and about of $40 \%$ of these particles are lower than $63 \mu \mathrm{m}$. A polycarboxlic-ether type superplasticizer (SP) with a specific gravity of 1.07 and a solid content of $30 \%$ was used.

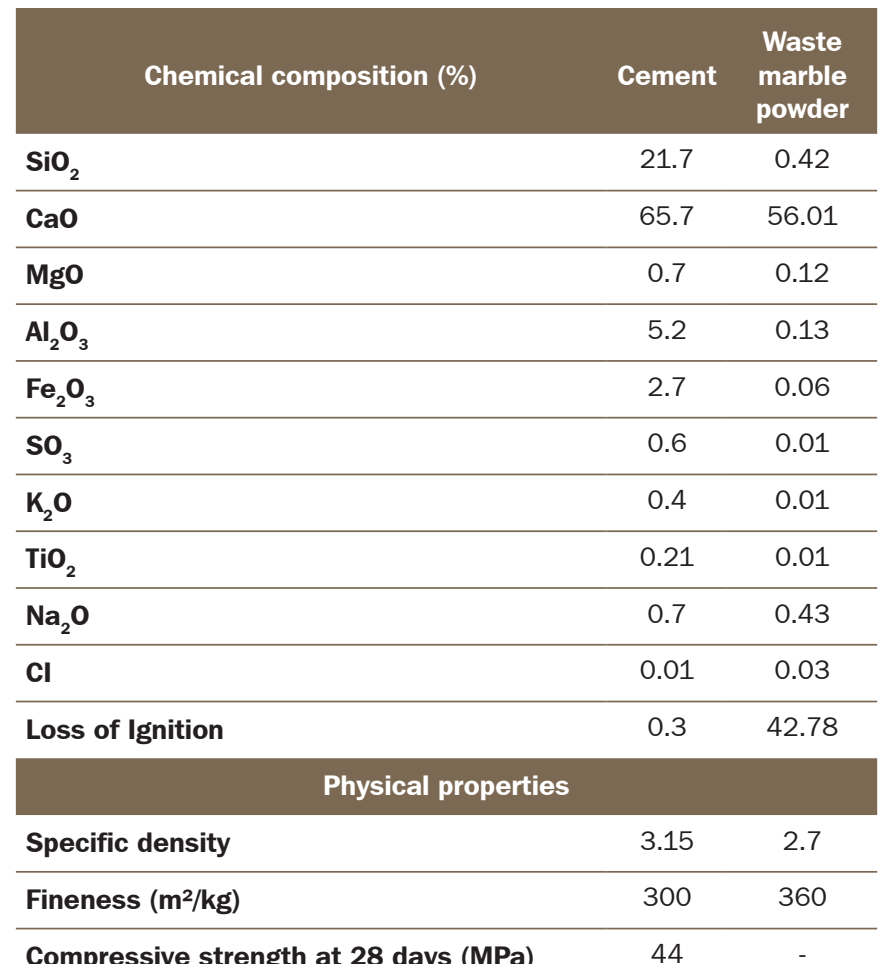

Compressive strength at 28 days (MPa)

44

Table 1. Chemical composition and physical properties of cement and waste marble powder

1. táblázat Cement és márvány hulladék por kémiai összetétele és fizikai jellemzői 

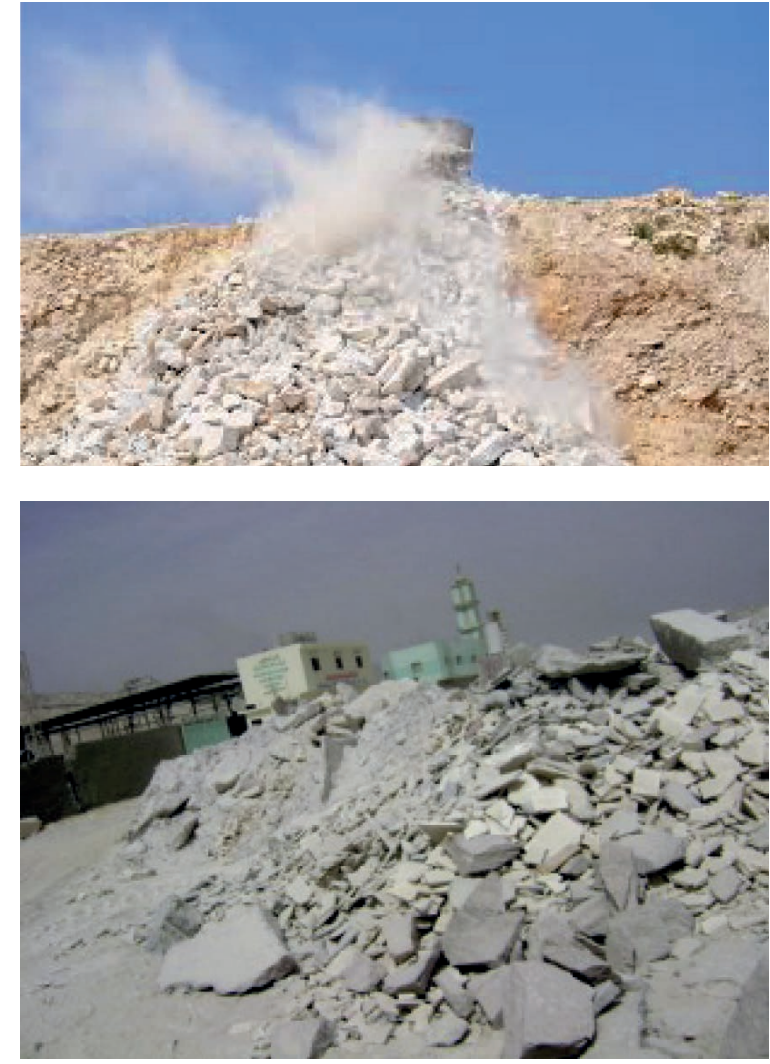

Fig. 1. Disposal of waste marble to the ground 1. ábra Hulladék márvány ártalmatlanítása

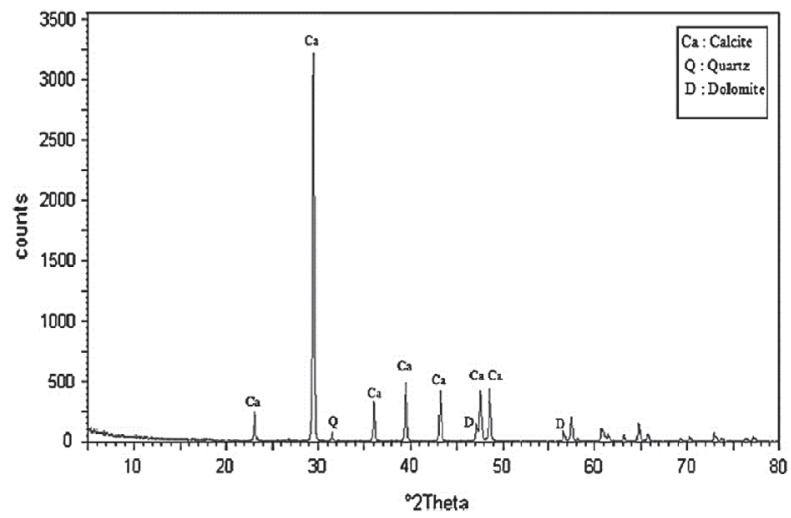

Fig. 2. X-ray diffraction of waste marble powder (WMP) 2. ábra Márvány hulladék por röntgendiffraktogramja

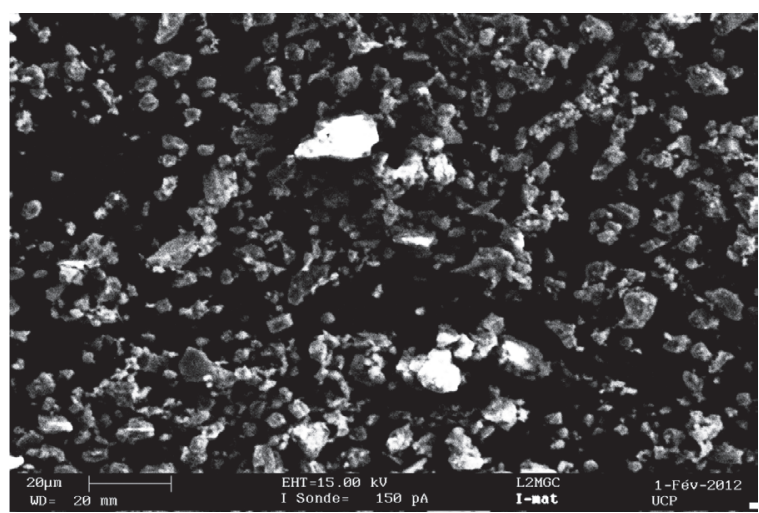

Fig. 3. SEM view of waste marble powder (WMP)

3. ábra Márvány hulladék por elektronmikroszkópos felvétele

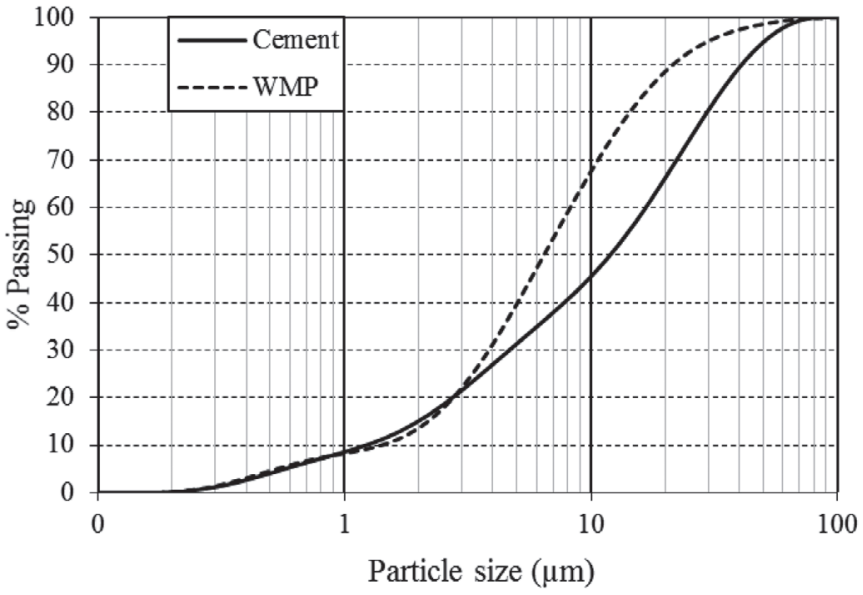

Fig. 4. Particle size distribution of cement and waste marble powder (WMP) 4. ábra Márvány hulladék por és cement szemeloszlása

Continuously graded coarse aggregates (CA) (3/8 and 8/15 $\mathrm{mm}$ ) were used in this study with a specific gravity and water absorption of 2.7 and $2.5 \%$ respectively. Various types of sand are used: river sand (RS) which is available natural source as shown in Fig. 5, crushed sand (CS) which is a waste of quarry stone crushing as seen in Fig. 6, and dune sand (DS) very available in the desert of Algeria as shown in Fig. 7. Mixtures of these sands in binary and ternary system are also used. The physical properties and sieve analysis results of these sands are given in Table 2 and Fig. 8 respectively. The maximum (D) dimension of RS, CS and DS sands were respectively 5,4 and $0.63 \mathrm{~mm}$. in order to determine the surface characteristics of the different sands, scanning electron microscope (SEM) was carried out and images of RS, CS and DS grains are given in Fig. 9. SEM investigations reveal the rounded shape of the RS and DS grains, and angular shape of CS grains. They show also the fineness and cleanness of DS compared to RS and CS, and the high filler content of CS. Moreover, X-ray diffraction analysis was performed; results are represented in Fig. 10. The X-ray diffraction analysis shows that RS and DS contain mainly the quartz $\left(\mathrm{SiO}_{2}\right)$ with some traces of calcite. However, CS contains the calcite $\left(\mathrm{CaCO}_{3}\right)$.

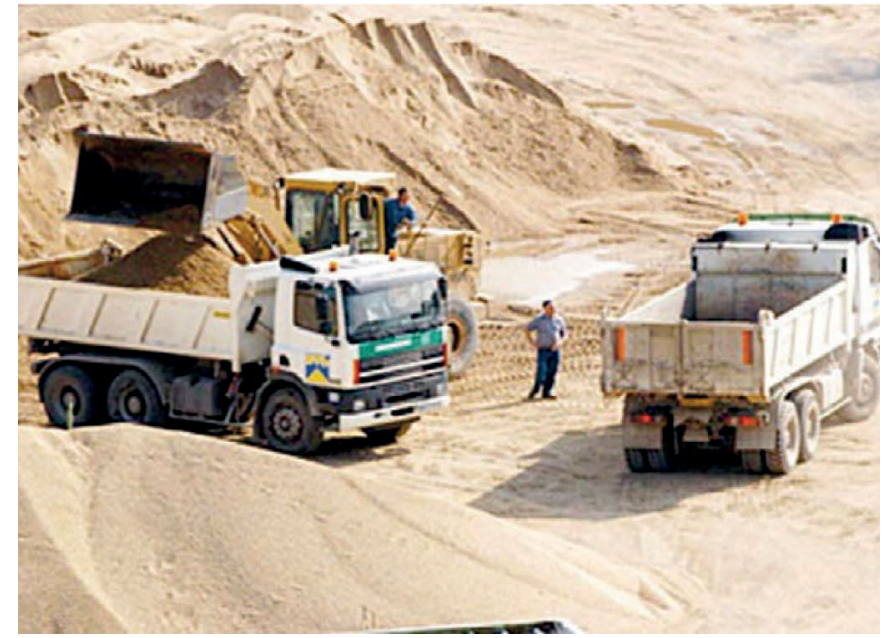

Fig. 5. Huge use of river natural sand (RS)

5. ábra Természetes folyami homok kitermelése 


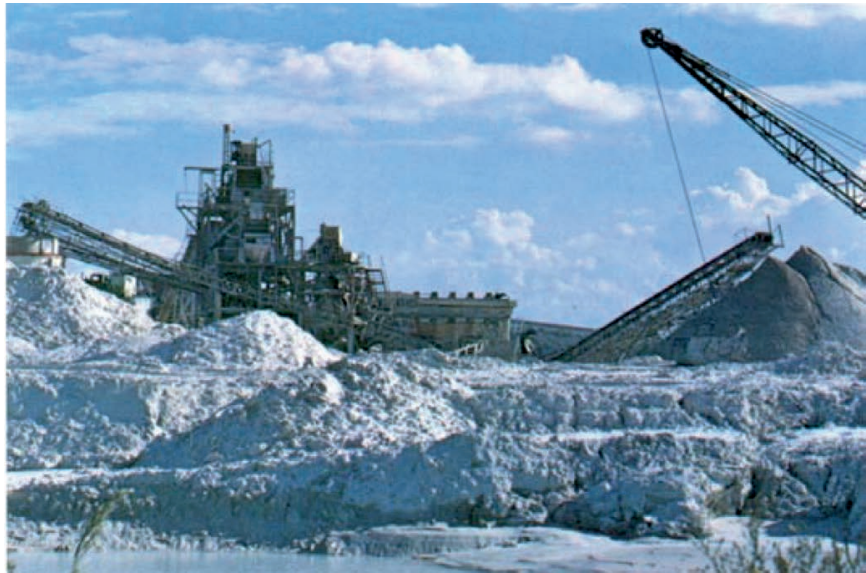

Fig. 6. Disposal of quarry crushed sand to the ground (CS)

6. ábra Zúzott bányahomok deponálása

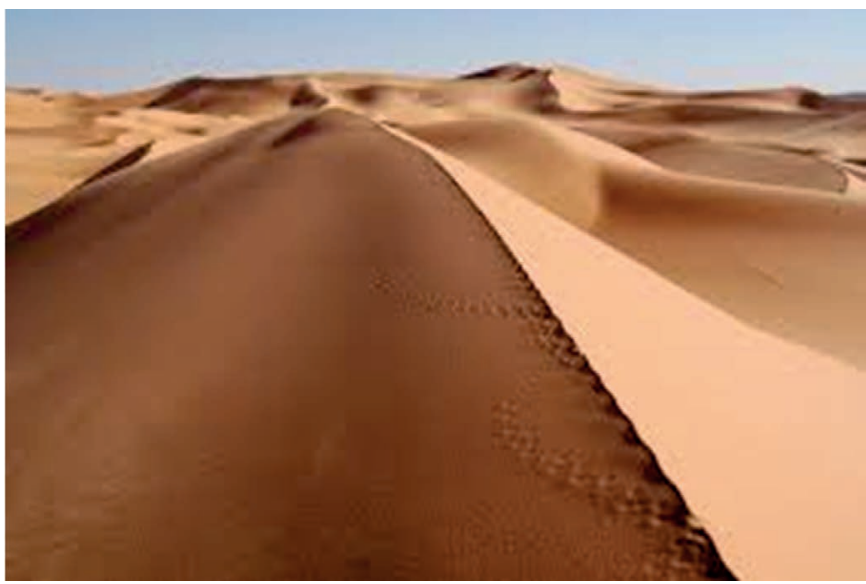

Fig. 7. Large quantities of dune sand in the desert of Algeria (DS)

7. ábra Algériai sivatagi düne homok

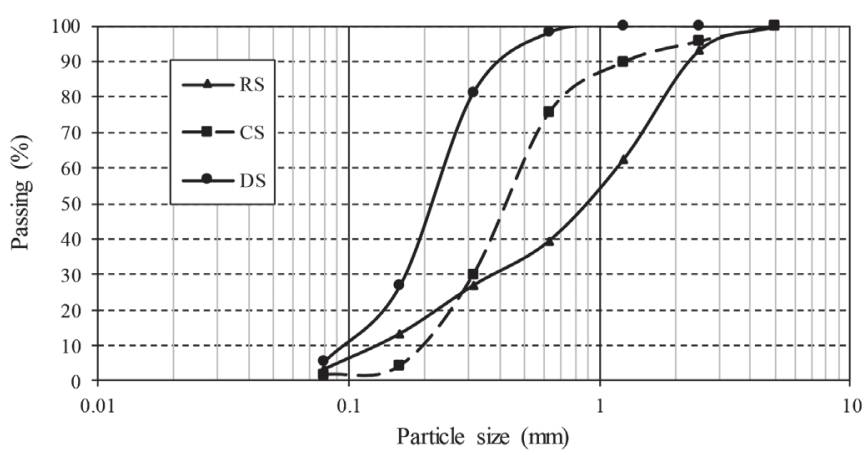

Fig. 8. Particle size distributions of different types of sand (RS, CS, DS) 8. ábra A felhasznált homokok szemeloszlása

\begin{tabular}{lccc}
\multicolumn{1}{r}{ Properties } & \multicolumn{3}{c}{ Sand type } \\
& CS & RS & DS \\
Specific gravity & 2.68 & 2.67 & 2.65 \\
\hline Unit weight $\left(\mathbf{k g} / \mathbf{m}^{3}\right)$ & 1541 & 1758 & 1520 \\
\hline Fineness modulus & 2.21 & 2.45 & 0.78 \\
\hline Sand equivalent $(\%)$ & 71 & 87 & 83
\end{tabular}

Table 2. Physical properties of the used sands

2. táblázat A felhasznált homokok fizikai jellemzői
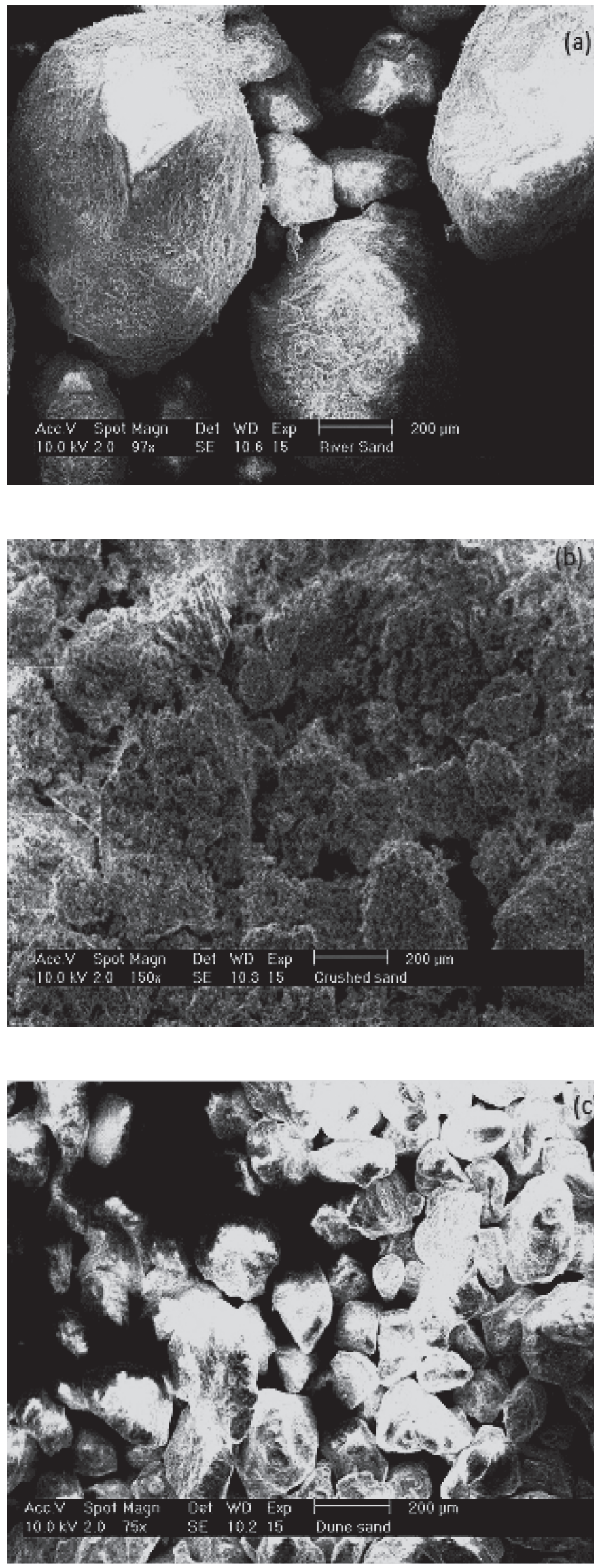

Fig. 9. SEM views of different types of sand: (a) RS; (b) CS; (c) DS

9. ábra A felhasznált homokok elektronmikroszkópos felvételei 

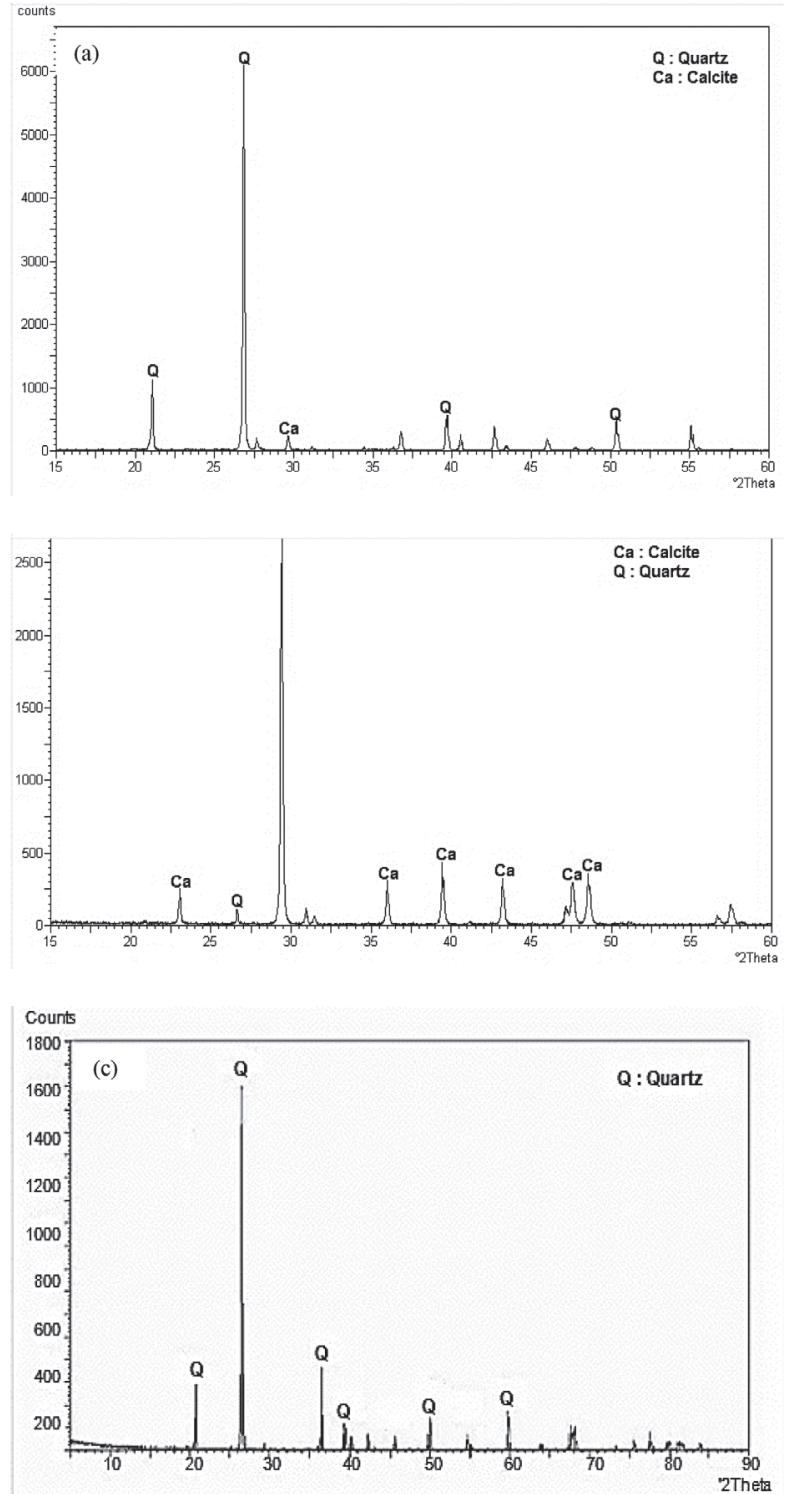

Fig. 10. X-ray diffraction of different types of sand: (a) RS; (b) CS; (c) DS 10. ábra A felhasznált homokok röntgendiffraktogramjai

\subsection{Mixture proportions}

SCC mixes were made, which had total powder binder (cement + marble powder) content of $475 \mathrm{~kg} / \mathrm{m}^{3}$. The coarse aggregates content was maintained at $31 \%$ by volume of cement for concrete and fine aggregates content at $50 \%$ by volume of mortar in concrete. The water to powder ratio $(\mathrm{W} / \mathrm{P})$ was fixed at 0.4 by weight with air-content being assumed to be $1 \%$. SCC mixes were prepared with different types of sand: crushed sand, river sand, dune sand and binary or ternary sands. The SCC mixture proportions are summarized in Table 3.

\subsection{Mixing procedure}

The mixing procedure and time are very important, thus the mixing process was kept constant for all concrete mixtures. The batching sequence consisted of homogenizing the powder and aggregates for $30 \mathrm{sec}$ in a rotary planetary mixer, then adding $70 \%$ of water and mixed for $1 \mathrm{~min}$. Thereafter remaining water (30\%) with SP was introduced, and the concrete was mixed for $5 \mathrm{~min}$, then the mixing was stopped for $2 \mathrm{~min}$ and again the concrete was further mixed for $30 \mathrm{sec}$ before it was discharged from the mixer.

\subsection{Concrete testing}

In this investigation, the slump flow test was used to evaluate the flow ability of self-compacting concrete in terms of mean spread diameter. The minimum value of self-compacting concrete to be $650 \mathrm{~mm}$ and a maximum of $800 \mathrm{~mm}$ for a fresh self-compacting concrete [52]. During the slump flow test, the time required to reach $50 \mathrm{~cm}$ diameter of slump flow is measured $\left(\mathrm{T}_{50}\right)$. The V-funnel test is used to determine the filling ability of the concrete. The time taken for the concrete to flow down is noted in seconds [53]. The maximum time that can be taken by a self-compacting concrete mix in V-funnel is 10 seconds. The passing ability was measured by L-Box test. The test was started by removing the control gate at once to allow the flow of selfcompacting concrete through the horizontal obstruction in the box and then the ratio of $\mathrm{H}_{2} / \mathrm{H}_{1}$ were determined, if the concrete flows freely as water, at rest it will be horizontal and therefore the

\begin{tabular}{|c|c|c|c|c|c|c|c|c|c|c|c|}
\hline Mix. $\mathbf{N}^{\circ}$ & $\begin{array}{l}\text { Mix. } \\
\text { code }\end{array}$ & $\begin{array}{c}{ }^{*}(\mathrm{C}+\mathrm{WMP}) \\
\left(\mathrm{kg} / \mathrm{m}^{3}\right)\end{array}$ & $\begin{array}{l}\text { CS } \\
\text { (\%) }\end{array}$ & $\underset{\left(\mathrm{kg} / \mathrm{m}^{3}\right)}{\mathrm{CS}}$ & $\begin{array}{l}\text { RS } \\
\text { (\%) }\end{array}$ & $\begin{array}{c}\text { RS } \\
\left(\mathbf{k g} / \mathrm{m}^{3}\right)\end{array}$ & $\begin{array}{l}\text { DS } \\
(\%)\end{array}$ & $\begin{array}{c}\text { DS } \\
\left(\mathrm{kg} / \mathrm{m}^{3}\right)\end{array}$ & $\underset{\left(\mathrm{kg} / \mathrm{m}^{3}\right)}{\mathrm{CA}}$ & $\begin{array}{c}\mathbf{S P} \\
\left(\mathbf{k g} / \mathrm{m}^{3}\right)\end{array}$ & $\begin{array}{c}\text { Water } \\
\left(\mathrm{kg} / \mathrm{m}^{3}\right)\end{array}$ \\
\hline SCC1 & 100CS & 475 & 100 & 886 & 0 & 0 & 0 & 0 & 830 & 2.9 & 190 \\
\hline SCC2 & 100RS & 475 & 0 & 0 & 100 & 886 & 0 & 0 & 830 & 4.2 & 190 \\
\hline SCC3 & 100DS & 475 & 0 & 0 & 0 & 0 & 100 & 886 & 830 & 7.1 & 190 \\
\hline SCC4 & $75 \mathrm{CS}+25 \mathrm{RS}$ & 475 & 75 & 665 & 25 & 222 & 0 & 0 & 830 & 2.9 & 190 \\
\hline ScC5 & 50CS+50RS & 475 & 50 & 443 & 50 & 443 & 0 & 0 & 830 & 2.9 & 190 \\
\hline SCC6 & $25 \mathrm{CS}+75 \mathrm{RS}$ & 475 & 25 & 222 & 75 & 665 & 0 & 0 & 830 & 2.9 & 190 \\
\hline SCC7 & $75 C S+25 D S$ & 475 & 75 & 665 & 0 & 0 & 25 & 222 & 830 & 2.9 & 190 \\
\hline ScC8 & $50 C S+50 D S$ & 475 & 50 & 443 & 0 & 0 & 50 & 443 & 830 & 2.9 & 190 \\
\hline SCC9 & $25 C S+75 D S$ & 475 & 25 & 222 & 0 & 0 & 75 & 665 & 830 & 2.9 & 190 \\
\hline SCC10 & $75 R S+25 D S$ & 475 & 0 & 0 & 75 & 665 & 25 & 222 & 830 & 4.2 & 190 \\
\hline SCC11 & 50RS+50DS & 475 & 0 & 0 & 50 & 443 & 50 & 443 & 830 & 4.2 & 190 \\
\hline SCC12 & $25 \mathrm{RS}+75 \mathrm{DS}$ & 475 & 0 & 0 & 25 & 222 & 75 & 665 & 830 & 4.2 & 190 \\
\hline SCC13 & $50 C S+25 R S+25 D S$ & 475 & 50 & 443 & 25 & 222 & 25 & 222 & 830 & 2.9 & 190 \\
\hline SCC14 & 25CS+50RS+25DS & 475 & 25 & 222 & 50 & 443 & 25 & 222 & 830 & 2.9 & 190 \\
\hline SCC15 & $25 C S+25 R S+50 D S$ & 475 & 25 & 222 & 25 & 222 & 50 & 443 & 830 & 2.9 & 190 \\
\hline
\end{tabular}

*(C+WMP): $90 \%$ Cement (C)+10\% waste marble powder (WMP) CS: crushed sand; RS: river sand; DS: dune sand; CA: coarse aggregate; SP: superplasticizer

Table 3. SCC mixture proportions with different types of sand

3. táblázat Öntömörödő betonok összetételei különböző homokok felhasználásával 


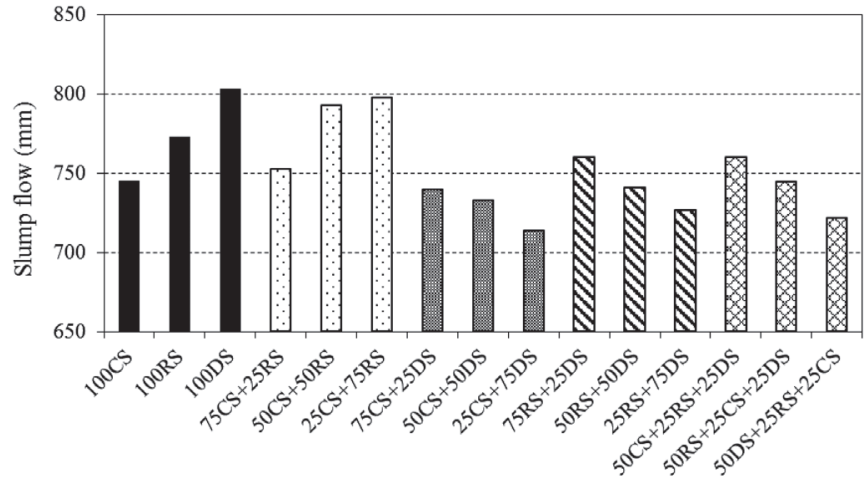

Fig. 11. Slump flow of SCC with different types of sand

11. ábra Öntömörödő beton roskadási terülése különbözö homokok felhasználásával

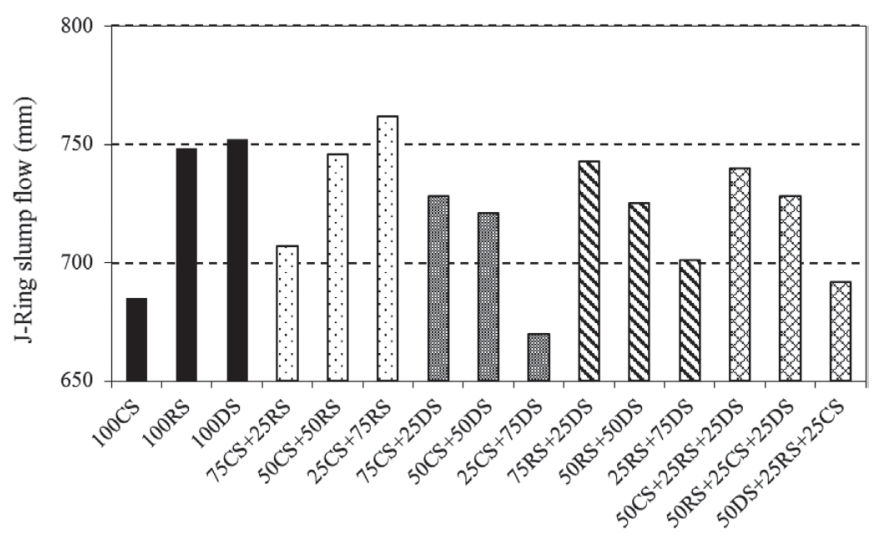

Fig. 12. J-Ring Slump flow of SCC with different types of sand

12. ábra Öntömörödö beton blokkológyürüs roskadási terülése különböző homokok felhasználásával

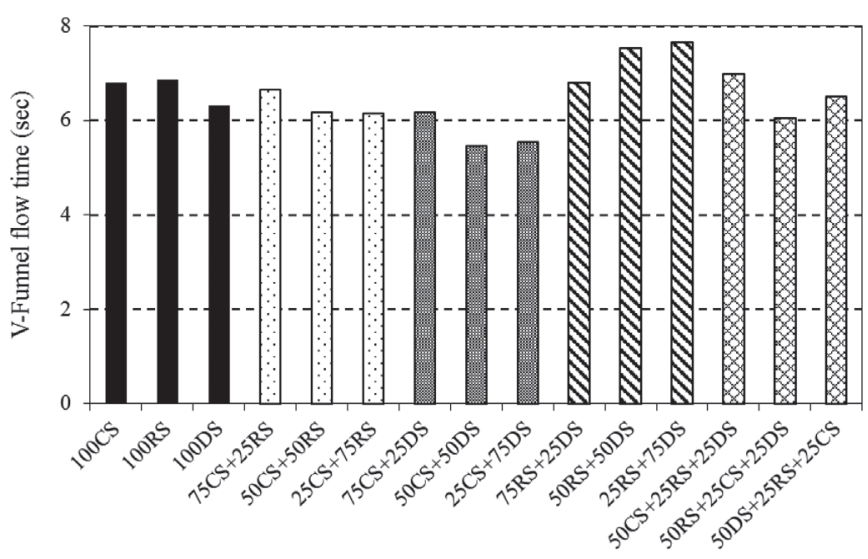

Fig. 13. V-Funnel flow time of SCC with different types of sand

13. ábra Öntömörödő beton kifolyási ideje különböző homokok felhasználásával

ration will be equal to unity. The minimum acceptable value is to be 0.8 [52]. J-Ring slump test was also used to evaluate the passing ability. The resistance to segregation was assessed by GTM sieve stability test. The minimum acceptable value is to be $15 \%$ [52].

For compressive strength tests, from each concrete mixture three prisms of $70 \times 70 \times 280 \mathrm{~mm}$ were cast. After removal from moulds, at $24 \mathrm{~h}$ of age, concrete specimens were immersed in water saturated with lime at $20^{\circ} \mathrm{C}$ until the age of testing. The compressive test was conducted at the age of 28 and 90 days for the different mix proportions according to NFP $15-451$ on the half samples obtained after the flexural test.

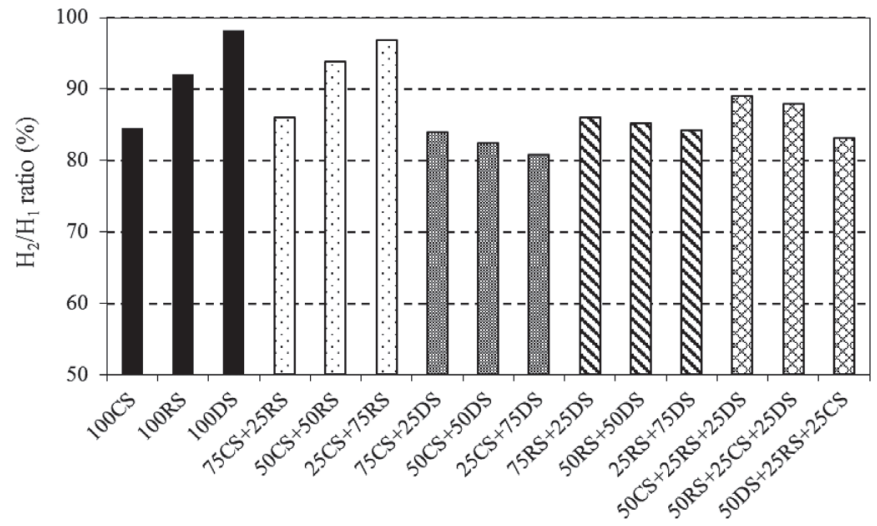

Fig. 14. L-Box filling high $\mathrm{H}_{2} / \mathrm{H}_{1}$ ratio of SCC with different types of sand 14. ábra Öntömörödő beton L-doboz H2/H1 feltöltési hányadosa különböző homokok felhasználásával

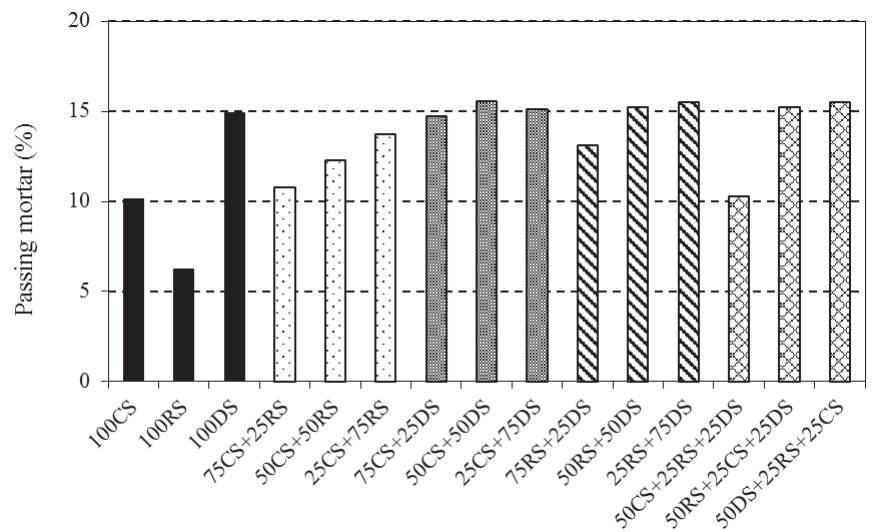

Fig. 15. Passing mortar using sieve stability test (GTM) of SCC with different types of sand

15. ábra Öntömörödő beton szitastabilitási (GTM) vizsgálata különböző homokok felhasználásával

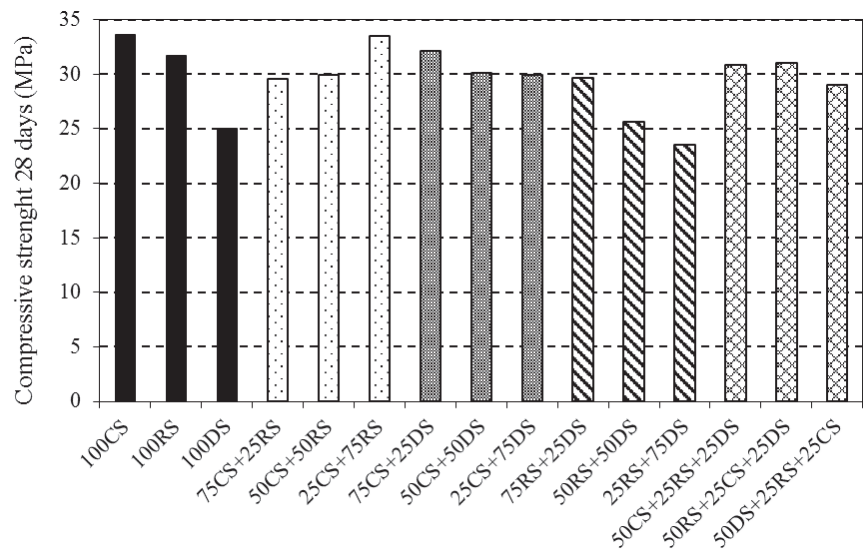

Fig. 16. Compressive strength at 28 days of SCC with different types of sand

16. ábra Öntömörödő beton nyomószilárdsága különbözö homokok felhasználásával 28 napos korban

\section{Results and discussion}

\subsection{Slump flow test}

The results of slump flow are presented in Fig. 11. It is noted, that the slump flow values of all SCC mixtures are in the range slump flow values defined by the AFGC recommendations [53]. It is remarked an increase in the slump flow of SCC with mixture sand of RS+CS, this increase becomes very important 
when the percentage of RS exceeds 50\%. A decrease in slump flow was observed in SCC with binary mixture sand of CS+DS and RS+DS, this decrease also becomes very important when the DS percentage is very high. Therefore, the addition of dune sand up to $25 \%$ improves the slump flow of SCC. Beyond this content of dune sand, the slump spread decreases and does not meet the criteria for self-compacting concrete, and behaves like an ordinary concrete. R'mili et al. $[50,51]$ studied the effect of the incorporation of crushed sand and desert sand on the properties of self-compacting concretes. The results show that the workability parameters are improved when the crushed sand is partially replaced by desert sand (dune sand). A substitution rate of $15 \%$ gives good workability in terms of flow spreading and $\mathrm{T}_{50}$ flow time. Beyond this sand dune content these parameters decrease and do not meet the criteria of a self-compacting concrete.

From this, it can be concluded that the river sand has a beneficial effect on the slump spread, unlike the dune sand, which reduces remarkably the slump spread of SCC. The SCC highly proportioned in DS required at the same time important proportioning in SP and in water. This is due to the large finesses of these sands and to their need for water causing an increase in the viscosity. A demand for additional water is then necessary to improve the workability behavior of these SCC. Omar et al. [54] studied the influence of crushed sand substitution with different percentages of 25,50 and $75 \%$ on the properties of concretes. They noticed that the use of crushed sand as fine aggregates improves the flow spreading of concrete due to the existence of fines. Gristsada and Natt [55] used calcareous sand to improve the properties of self-compacting concretes. They noticed an increase in flow spreading with increasing dosage in calcareous sand. A substitution rate of $60 \%$ gave the best flow spreading of the used concretes.

\subsection{J-Ring slump flow}

The J-Ring spread results are shown in Fig. 12. It is noticed an increase in the J-Ring spreading in SCC with binary system mixture sand of CS+RS. On the other hand, a decrease in the spreading with the increase of the percentage of DS in SCC with binary sand and ternary system mixture of CS+RS+DS. This means that the high dosage of DS remarkably decreases the spread of SCC, hence the flowability of SCC. Nanthagopalan and Santhanam [57] studied the fresh properties of SCC prepared with crushed sand. They noted that the spread of SCC increases with the use of crushed sand compared to SCC made with natural sand. This is due to the increase in paste volume due to the existence of fines in the crushed sand [7].

\subsection{V-funnel flow time}

The results of the flow time using the V-Funnel test are shown in Fig. 13. This test indicates the filling capacity of mixture. The test of the flow through the funnel in $\mathrm{V}$ is a way to evaluate the viscosity and resistance to segregation of concrete. From Fig. 13, it can be noted that the values of the flow time through V- funnel are included in the interval $(6-12 \mathrm{sec})$ proposed by Domone [48]. The addition of DS increases the flow time of SCC compared to that with RS, but the recorded values of the flow time meet the recommendations of SCC production. $R^{\prime} m i l i$ et al. [50] have noted that the substitution of crushed sand by a sand dune in the composition of self-compacting concretes, allows to increasing the flow time to the V-funnel. This is explained by the increasing the viscosity up to a rate of $30 \%$. Beyond this content, the SCC required an addition of water and superplasticizer to have self-placing properties [51]. One can say even with moderate dosages of DS that the measured flow time shows that incorporation of DS increases the viscosity of SCC and this is due to the increase of the specific surface area of fine aggregate of binary or ternary mixture. Gristsada and Natt [55] have studied the properties of SCC with calcareous sand. They noticed that the flow time increases with the increase of the sand content. This is explained by the increase of the compactness of the mixture and consequently the increase of the viscosity.

\subsection{L-box test}

The results of variation of $\mathrm{H} 2$ / $\mathrm{H} 1$ using L-box test are shown in Fig. 14. It is seen that all results comply with the requirements of AFGC recommendations $\left(\mathrm{H}_{2} / \mathrm{H}_{1}>0.8\right)$ [53]. It is also noted a decrease in $\mathrm{H}_{2} / \mathrm{H}_{1}$ in SCC with binary and ternary mixtures sands when the sand dune percentage is above $50 \%$. The partial incorporation of DS in the mixtures increases the filling capacity of SCC, and therefore the mobility of SCC in confined areas. R'mili et al. [50] studied the effect of the incorporation of crushed sand and desert sand on the properties of self-compacting concretes. The results show that the L-box filling capacity is improved when the crushed sand is partially replaced by desert sand (dune sand). The $\mathrm{H}_{2} / \mathrm{H}_{1}$ ratio increases to a substitution rate of $15 \%$. Beyond this sand dune content, this ratio decreases. For high amounts of DS, SCC behave like ordinary concrete. The use of binary and ternary mixtures sands improves the rheological properties of SCC. $R^{\prime} m i l i$ et al [50] have studied the effect of the incorporation of crushed sand and desert sand on properties of self-compacting concrete. The results show that the ability to fill in L-box is improved when the crushed sand is partially replaced by the desert sand. Kou and Poon [59] prepared a SCC with natural and recycled sand. The replacement rate of natural sand by recycled sand is $0,25,50,75$ and $100 \%$. They noticed an increase in $\mathrm{H}_{2} / \mathrm{H}_{1}$ ratio with increases in percentage of recycled sand.

\subsection{Sieve stability test}

Sieve stability test (GTM) results are shown in Fig. 15. It is noted that the percentages of mortar passing through the sieve are between 6 and 15\% according to recommendations ENFRAC [52], except for SCC with DS as partial replacement of RS or CS in binary and ternary system mixtures, which are slightly over than the recommended values for SCC, but remain acceptable values. This is due to high percentage of DS used in blends, since the latter has a fine particle size that passes through the sieve with the amount of milt. Generally, the results obtained show that all SCC have good resistance to segregation and bleeding. Further, visual examination of SCC reveals that they are homogeneous and stable. The use of CS with RS or DS increases the volume of the paste and therefore improves the stability of the SCC. 


\subsection{Compressive strength}

Fig. 16 shows the variation of the compressive strength of different SCC at 28 days. It can be noted that, the best strengths achieved after 28 days are obtained with SCC made with mixture sand of river and crushed sand. It is shown that the river sand has a beneficial effect on the compressive strength of SCC due to its continuous particle size. However, the strength gain for SCC containing crushed sand appears to be linked to the existence of limestone fines in sand in one hand, and in other hand the large size of the crushed sand. Abdulghani [60] studied the effect of sand size on the properties of selfcompacting concretes. He noticed that, the resistance is not significantly affected by the size of fine aggregates. The sharp edges of the particles in crushed sand provide better bond with cement than rounded particles of river sand. Shaik and Diami [61] carried out a study on the mechanical properties of concretes made with industrial sand (crushed sand) and natural sand (river sand). They have demonstrated that industrial sand used as fine aggregates can significantly improve the mechanical properties of concrete. The crushed aggregates with angular shape confer a good bond granulate-cement compared to rolled aggregates. Kothai and Malthy [62] carried out a study on the influence of replacing natural sand with crushed sand on the mechanical strength of self-compacting concrete. They found that a substitution rate of natural sand by industrial sand or crushed of $30 \%$ gives good mechanical strength in terms of compressive, tensile and flexural strength. A reduction in the compressive strength was observed in SCC with binary and ternary mixtures of crushed- dune sand, river - dune sand and crushing- river -dune sand. This means that the dune sand decreases compressive strength of SCC due to its very fine particle size, high surface area and high porosity, which gives less compactness of SCC than those made with river and crushed sand $[63,64]$. R'mili et al. [50] found that the partial substitution (30\%) of crushed sand by desert sand (dune sand) in the composition of self-compacting concretes, contributed to the improvement of mechanical resistance. Beyond $30 \%$ substitution of dune sand resistances decrease, but they reach acceptable values compared to ordinary concrete.

\subsection{Microstructure}

Since the siliceous sand is inert, the increase in strength is obtained by densification of the matrix and the matrixaggregate interface. In the case of sand limestone and silicolimestone, adds to the densification an interaction between the matrix and the aggregates, which gives good adhesion sand-cement paste and increases the strength. This is verified by the SEM examination of the samples, which shows crack propagation through the cement paste and aggregates. Fig. 17 represents SEM examinations of SCC with 100\% RS, 100\% CS and $100 \%$ DS respectively. The crack propagation is observed through the cement paste.

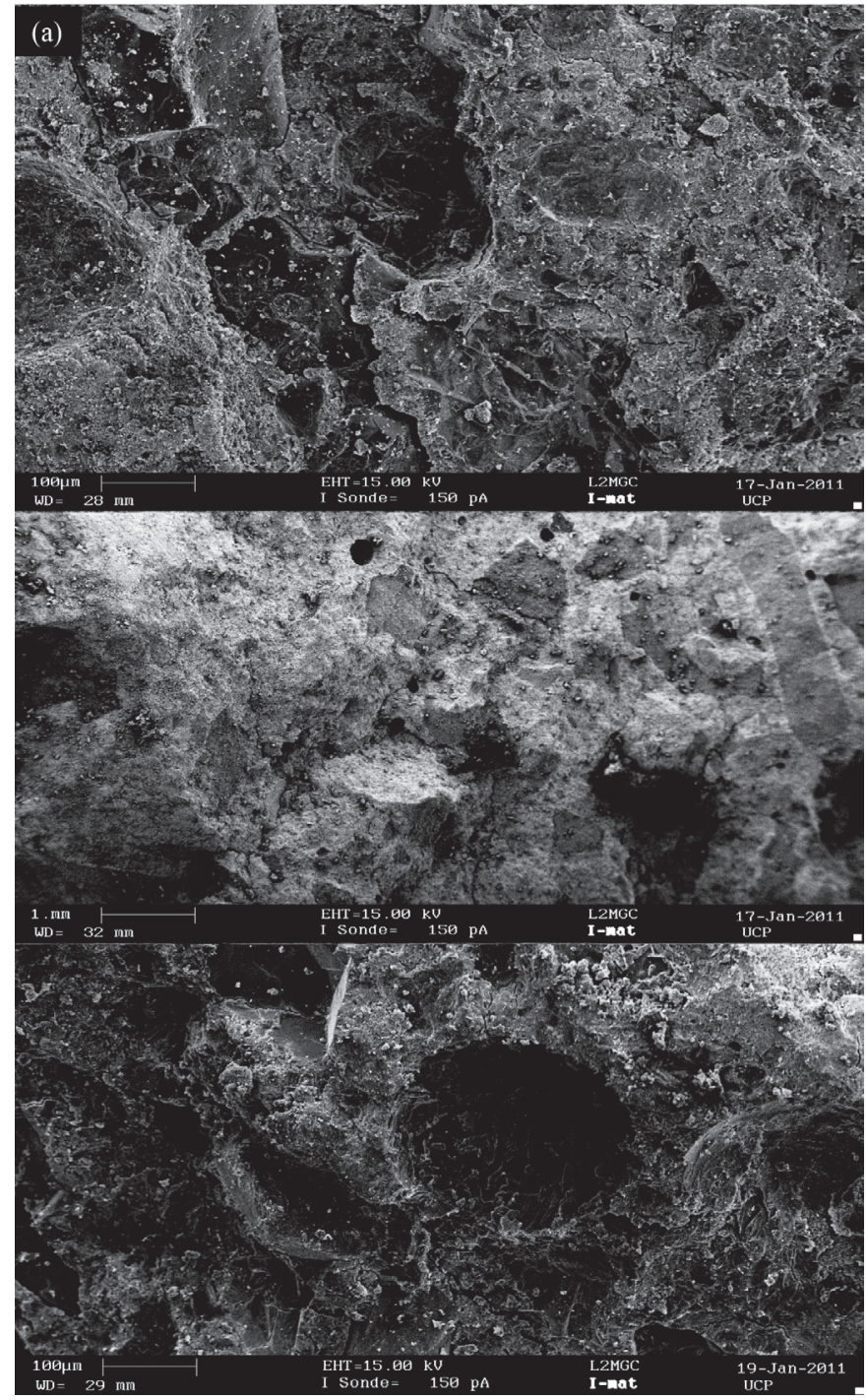

Fig. 17. SEM views of SCC with different types of sand: (a) 100\% RS; (b) 100\% CS; (c) $100 \%$ DS

17. ábra Öntömörödő beton elektronmikroszkópos felvételei különböző homokok felhasználásával, (a) 100\% RS; (b) 100\% CS; (c) 100\% DS

Bellanger et al. [68] observed in this connection that the character of the fracture, in mortar or concrete, differed according to the type of a: it is always intergranular in a siliceous concrete, it is intergranular in the case of hard limestone aggregates, and intragranular when the paste is less deformable than the aggregate. Bachiorrini [69] has also observed changes in the mode of crack propagation in aluminous calcareous sand mortars. Different authors have studied the properties of calcareous aggregates in a cement matrix. Husson [70] has shown that limestone fines were active within a cement matrix and that they participated in hydration reactions by forming between others carboaluminates. To highlight this phenomenon, Husson [70] worked on calcite $\left(98.6 \% \mathrm{CaCO}_{3}\right)$ with a particle size slightly smaller than that of the binder. Other authors [70] have shown that the composition of the interfacial zone could be modified when the aggregate is reactive (e.g. calcite) by the formation of carboaluminates, calcium carbonate complexes, calcium hydroxide. Therefore, the surface of the aggregates was attacked by the formation of these compounds. Interface resistance tests 
have shown that for these reactive aggregates, the fracture was farther away than at the surface of the aggregate. The further the breaking zone is from the aggregate, the higher the resistance at the interface [71].

Bellanger et al. [72] have demonstrated the contribution of these chemical interactions on the mechanical strength, both in flexural and compressive strength, on mortars or concretes based on calcareous aggregates compared to the same materials with siliceous aggregate. They have also shown, with a succession of charge-discharge cycles, that calcareous sand mortar and concrete have an almost perfect elastic character, that is to say that the deformations are quasi-reversible up to $80 \%$ maximum stress. Under the same conditions, siliceous concrete has shown irreversible deformations for much lower stresses.

\section{Conclusions}

The assessment of the behavior of SCC at fresh and hardened state leads to the followings:

- The use of binary and ternary mixtures sands improves the rheological and mechanical properties of SCC.

- At different contents of river and crushed sand, the rheological and mechanical characteristics are met and comply with recommendations of the manufacturing of SCC. However, the use of high dosages of sand dunes reduces the rheological parameters of SCC. Therefore, to meet the self-compacting properties, additional amounts of water and superplasticizer are strongly required.

- The best strengths are obtained for SCC made with crushed and river sand. This is due to the good size distribution of these sands. The mechanical strengths decreased by adding a high content of dune sand but they reach acceptable values.

Based on the obtained results, it can be argued that the use of locally available materials in the manufacturing of concrete can be an economic and technological important alternative in some developing countries. The partial incorporation of the sand dune in the composition of self-compacting concrete can provide a solution for some work in the southern regions of the country where this material is very abundant. Moreover, crushed limestone sands are interesting alternative source to replace the river sand (rolled) for making any kind of concrete.

\section{References}

[1] Okamura, H. - Ouchi, M. (1999): Self-compacting concrete, development, present use and future, in: A. Skarendahl, O. Petersson (Eds.), SelfCompacting Concrete, RILEM Symposium Stockholm, RILEM Publications, 3-14, 1999 .

[2] Okamura, H. - Ouchi, M. (2003). Self-compacting concrete, Journal of Advanced Concrete Technology, 1: 5-15, 2003. https://doi.org/10.3151/jact.1.5

[3] Sonebi, M. (2004): Medium strength self-compacting concrete containing fly ash: modeling using factorial experimental plans, Cement and Concrete Research, 34:1199-208, 2004

https://doi.org/10.1016/j.cemconres.2003.12.022
[4] Sonebi, M. - Bartos P. J. (1999): Hardened SCC and its bond with reinforcement, Proceedings of First International RILEM Symposium on Self-Compating Concrete (PRO 7), Stockholm, Sweden, 1999.

[5] Uysal, M. - Yilmaz, K. - Ipek, M. (2011): The effect of mineral admixtures on mechanical properties, chloride ion permeability and impermeability of self-compacting concrete, Construction and Building Materials, 27: 26370, 2011. https://doi.org/10.1016/j.conbuildmat.2011.07.049

[6] Sadek, D. M. - El-Attar, M. M. - Haitham, A. A. (2016): Reusing of marble and granite powders in self-compacting concrete for sustainable development. Clean Production, 121: 19-32, 2016. https://doi.org/10.1016/j.jclepro.2016.02.044

[7] Felekoglu, B. (2008): A comparative study on the performance of sands rich and poor in fines in self-compacting concrete, Construction and Building Materials, 22: 646-654, 2008. https://doi.org/10.1016/j.conbuildmat.2006.10.007

[8] Bosiljkov, V. B. (2003): SCC mixes with poorly graded aggregate and high volume of limestone filler, Cement and Concrete Research, 33:1279-1286, 2003. https://doi.org/10.1016/S0008-8846(03)00013-9

[9] Ho, D. W. S. - Sheinn, A. M. M. - Ng, C. C. - Tam, C. T. (2002): The use of quarry dust for SCC application, Cement and Concrete Research, 32: 505-511, 2002. https://doi.org/10.1016/S0008-8846(01)00726-8

[10] Felekoglu, B. (2007): Utilisation of high volumes of limestone quarry waste in concrete industry (SCC case), Resources Conservation and Recycling, 51: 770-791, 2007. https://doi.org/10.1016/j.resconrec.2006.12.004

[11] Menadi, B. - Kenai, S. - Khatib, J. - Ait, Mokhtar A. (2009): Strength and durability of concrete incorporating crushed limestone sand, Construction and Building Materials, 23: 625-33, 2009. https://doi.org/10.1016/j.conbuildmat.2008.02.005

[12] Guimaraes, M. S. - Valdeo, J. R. - Palomino, A. M. - Santamarina, J. C. (2007): Aggregate production: fines generation during rock crushing, International Journal of Mineral Process, 81: 237-47, 2007. https://doi.org/10.1016/j.minpro.2006.08.004

[13] Johansen, K. - Mortsell, E. - Lindgard, J. (2000): Effect of adding natural fine sand rich in fines on the fresh concrete properties, Nordic concrete Research Publications, 22, 2000.

[14] Donza, H. - Cabrera, O. - Irrassar, E. F. (2002): High strength with different fine aggregate, Cement and Concrete Research, 32: 1755-1761, 2002. https://doi.org/10.1016/S0008-8846(02)00860-8

[15] Johansen, K. - Busterud, L. (2001): Low grade SCC with secondary natural sand rich in fine. In: Ozawa K, Ouchi M, editors, Second International RILEM Symposium on SCC, Japan, 2001.

[16] Topoçu, I. B. - Ugurlu, A. (2003): Effect of the use of mineral filler on the properties of concrete, Cement and Concrete Research, 33: 1071-1075, 2003. https://doi.org/10.1016/S0008-8846(03)00015-2

[17] Topoçu, I. B. (1999): Effects of using crushed stone dust on concrete properties. In: Tenth engineering symposium, Civil Engineering'99, Suleyman Demirel University, Isparta, Turkey, 1999.

[18] Okamura, H. - Maekawa, K. - Ozawa, K. (1993): High performance concrete, $1^{\text {st }}$ edition: Gihoudou Publication, Tokyo, 1993.

[19] Celik, T. - Marar, K. (1996): Effects of crushed stone dust on some properties of concrete, Cement and Concrete Research, 26: 1121-1130, 1996. https://doi.org/10.1016/0008-8846(96)00078-6

[20] Dehwah, H. A. F. (2012): Mechanical properties of self-compacting concrete incorporating quarry dust powder, silica fume or fly ash, Construction and Building Materials, 26: 547-551, 2012. https://doi.org/10.1016/j.conbuildmat.2011.06.056

[21] Jain, M. E. M. - Safiuddin, M. - Yousuf, K. M. (1999): A study on the properties of freshly mixed high performance concrete, Cement and Concrete Research, 29(9), 1427-1432, 1999. https://doi.org/10.1016/S0008-8846(99)00108-8

[22] Lohani, T. K.. - Padhi, M. - Jena, S. (2012): Optimum utilization of quarry dust as partial replacement of sand in concrete, International Journal of Applied Science and Engineering Research, Vol.1, No.2, 391-404, 2012.

[23] Hudson, B. P. (1997): Manufactured sand for concrete. The Indian Concrete Journal. 71(5): 237-240, 1997. 
[24] Sahu, A. K. - Kumar Sunil, Sachin A. K. (2003): Crushed stone waste as fine aggregate for concrete. The Indian Concrete Journal. 77(1): 845-847, 2003.

[25] Chitlange, M. R.. - Pajgade, P. S.. - Nagarnaik, P. B. (2008): Artificial sand as fine aggregate for concrete. Civil Engineering and Construction Review. 21 (12): 64-67, 2008.

[26] Kode, V. R. - Murty, D. S. R. - Swarna, Kumar P. (2007): Appraisal of crushed stone dust, as fine aggregate in structural concrete. Civil Engineering and Construction Review. 20(7): 52-58, 2007.

[27] Ahmed, A. E. - El-Kourd, A. A. (1989): Properties of concrete incorporating natural and crushed stone very fine sand. ACI Materials Journal. 86(4): 417-424, 1989.

[28] Ahmad, S. - Mahmood, S. (2008): Effects of crushed and natural sand on the properties of fresh and hardened concrete, $33^{\text {rd }}$ Conference on Our World In Concrete \& Structures, Singapore, pp. 25-27, 2008.

[29] Akrout, K. - Mounanga, P. - Ltifi, M. - Jamaa, N. (2010): Rheological, mechanical and structural performances of crushed limestone sand concrete, International Journal of Concrete Structures and Materials, Vol. 4, No. 2: 97-104, 2010. DOI 10.4334/IJCSM.2010.4.2.97

[30] Ilangovana, R. - Mahendrana, N. - Nagamanib, K. (2008): Strength and durability properties of concrete containing quarry rock dust as fine aggregates, ARPN Journal of Engineering and Applied Science, Vol.3(5), pp 20-26, 2008

[31] Hameed, M. S. - Sekar, A. S. S. (2009): Properties of green concrete containing quarry rock dust and Marble sludge powder as fine aggregates, ARPN journal of Engineering and applied Science, Vol.4(4), pp 83-89, 2009.

[32] Shi-Cong, K. - Chi-Sun, P. (2009): Properties of concrete prepared with crushed fine stone, furnace bottom ash and fine recycled aggregate as fine aggregates. Construction and Building Materials 23: 2877-2886, 2009. https://doi.org/10.1016/j.conbuildmat.2009.02.009

[33] Donza, H. - Cabrera, O. - Irassar, E. F. (2002): High-strength concrete with different fine aggregate. Argentina, Cement and Concrete Research. 32, 1755-1761, 2002. https://doi.org/10.1016/S0008-8846(02)00860-8

[34] Poon, C. S. - Shui, Z. H. - Lam, L. - Fok, H. - Kou, S. C. (2004): Influence of moisture states of natural and recycled aggregates on the slump and compressive strength of concrete, Cement and Concrete Research, Vol.34, Iss.1, 31-36, 2004. https://doi.org/10.1016/S0008-8846(03)00186-8

[35] Rao, K. B. - Desai, V. B. - Mohan, D. J. (2011): Experimental investigation on mode II fracture of concrete with crushed granite stone fine aggregate replacing sand, Material Research, Vol.15, No.1, 41-50, 2011.

[36] Kumar, P. - Kaushik, S. K. (2005): SCC with crusher dust, fly ash and micro silica. The Indian Concrete Journal. 79(8): 32-37, 2005.

[37] Shanmugapriya, T. - Uma, R. N. (2012): Optimization of partial replacement of $\mathrm{m}$-sand by natural sand in high performance concrete with silica fume, International Journal of Engineering Sciences \& Emerging Technologies, Vol. 2, pp. 73-80, 2012.

[38] Raman, S. N. M. - Zain, F. M. - Mahmud, H. B. - Tan, K. S. (2005): Influence of quarry dust $\&$ fly ash on the concrete compressive strength development. Proc. AEESEAP Int. Conf. 2005. Kuala Lumpur, Malaysia, 78, 2005.

[39] Reddy, M. V. - Reddy, C. N. V. S. (2007): An experimental study of rock flour and insulator ceramic scrap in concrete, Journal of Institute of Engineer (India), Vol. 88, pp 47-50, 2007.

[40] Bederina, M. - Khenfer, M. M. - Dheilly, R. M. - Quéneudec, M. (2005): Reuse of local sand: effect of limestone filler proportion on the rheological and mechanical properties of different sand concretes. Cement and Concrete Research, 35: 1172-1179, 2005. https://doi.org/10.1016/j.cemconres.2004.07.006

[41] Brouwers, H. J. H. - Radix, H. J. (2005): Self-compacting concrete: the role of the particle size distribution. In: First International Symposium on Design, Performance and Use of SCC. Hunan, China; 109-118, 2005.

[42] Kay, A. - Freason, J. (1994): An investigation into the use of dune sand in concrete. In: Fookes, Party, editor. In Proceeding of the $1^{\text {st }}$ International Symposium on Engineering Characteristics of Arid Soils. Rotterdam: Balkema, 261-672, 1994.
[43] Banfill, P. F. G. - Carr, M. P. (1987): The properties of concrete made with very fine sand. Concrete; 21: 11-16, 1987.

[44] Laquerbe, M. - Cisse. I. - Ahouansou, G. (1995): For a rational use of lateritic gravel and dune sand as aggregates in concrete: application to the case of Senegal. Materials and Structures, 28: 604-610, 1995.

[45] Tayeb, B. - Abdelbaki, B. - Madani, B. - Mohamed, L. (2011): Effect of Marble Powder on the Properties of Self-Compacting Sand Concrete, The Open Construction and Building Technology Journal, 5, 25-29, 2011

[46] Bouziani, T. - Bederina, M. - Hadjoudja, M. (2012): Effect of dune sand on the properties of flowing sand-concrete (FSC). International Journal of Concrete Structures and Materials, 6: 59-64, 2012.

https://doi.org/10.1007/s40069-012-0006-z

[47] Bouziani, T. (2013): Assessment of fresh properties and compressive strength of self-compacting concrete made with different sand types by mixture design modelling approach. Construction and Building Materials, 49: 308-314, 2013. https://doi.org/10.1016/j.conbuildmat.2013.08.039

[48] Bouziani, T. - Bédérina, M. - Makhloufi, Z. - Hadjoudja, M. (2014): Mixture design approach to evaluate fresh properties of SCC made with various sands. Journal of Building Materials and Structures, 1: 1-9, 2014.

[49] Bouziani, T. - Benmounah, A. - Makhloufi, Z. - Bédérina, M. Queneudec, M. (2014): Properties of flowable sand concretes reinforced by polypropylene fibers. Journal of Adhesion Science and Technology, 28: 1823- 1834, 2014. https://doi.org/10.1080/01694243.2014.924176

[50] R’mili, A. - Ben Ouezdou, M. - Added, M. - Ghorbel, I. (2009): Incorporation of crushed sands and Tunisian desert sands in the composition of self-compacting concrete, Part II: SCC fresh and hardened states characteristics, International Journal of Concrete Structures and Materials, 3: 11 - 14, 2009.

[51] R'mili, A. - Ben Ouezdou, M. (2011): Incorporation of crushed sand and desert sand in the composition of Self-Compacting Concrete, International conference, Innovation and Valorization in civil engineering and construction materials, N10-271, Rabat, Morocco, 2011. https://doi.org/10.4334/IJCSM.2009.3.1.011

[52] EFNARC (2005): The European guidelines for self-compacting concrete, The European Federation of Specialist Construction Chemicals and Concrete Systems, p. 68, 2005

[53] AFGC (2002): French Association of Civil Engineering, Guidelines for selfcompacting concrete: scientific and technique documents, 2002.

[54] Omar, O. M. - Abd El-hameed, G. D. - Sherif, M. A. - Mohamadien, H. A. (2012): Influence of limestone waste as partial replacement material for sand and marble powder in concrete properties, Journal of Housing and Building National Research Center, 8: 193 - 203, 2012.

[55] Gritsada, Sua-iam - Natt, Makul (2013): Utilization of limestone powder to improve the properties of SCC incorporating high volumes of untreated rice husk ash as fine aggregate, Construction and Building Materials 38: 455 - 464, 2013. https://doi.org/10.1016/j.conbuildmat.2012.08.016

[56] Domone, P. L. - Jin, J. - Chai, H. W. (1999): Optimum mix proportioning of self-compacting concrete, Innovation in Concrete Structures: Design and Construction, Proceeding of creating with concrete, University of Dundee, September 1999, 277 - 285

[57] Nanthagopalan, P. - Santhanam, M. (2011): Fresh and hardened properties of self-compacting concrete produced with manufactured sand, Cement and Concrete Composites, 33: 353 - 358, 2011. https://doi.org/10.1016/j.cemconcomp.2010.11.005

[58] Domone, P. L. - Jin, J. (1999): Properties of mortar for Self-Compacting Concrete, Proceedings of the 1st International Symposium on SCC, RILEM Proceedings PRO 7, Sweden, 1999.

[59] Kou, S.C. - Poon, C. S. (2009): Properties of SCC prepared with coarse and fine recycled aggregates, Cement and Concrete Composites, 31: 622 627, 2009. https://doi.org/10.1016/j.cemconcomp.2009.06.005

[60] Abdul Ghani Zghair Luma (2010): Influence of fine aggregate grading on some properties of SCC, Journal of Engineering and Development, 14: 18 37,2010 , 
[61] Shaikh, M. G.. - Daimi S. A. (2011): Durability studies of concrete made by using artificial sand with dust and natural sand, International Journal of Earth Sciences and Engineering, 04: 823 - 825, 2011,

[62] Kothai, L. - Malathy, R. (2012): Strength studies on self-compacting concrete with manufactured sand as partial replacement of natural sand, European Journal of Scientific Research, Vol. 89, N 3: 490 - 496, 2012,

[63] Elyamany, H. E. - Abd Elmoaty, M. A. E. - Mohamed, B. (2014): Effect of filler types on physical, mechanical and microstructure of self-compacting concrete and Flow-able concrete, Alexandria Engineering Journal, 53: 295307, 2014. https://doi.org/10.1016/j.aej.2014.03.010

[64] Lasintha, E. D. L. - Prabath, R. M. T. - Sooriaarachchi, H. P. (2012): Influence of fine aggregate types on the performance self-flowing concrete, Proceedings of International Symposium on Advances in Civil and Environmental Engineering Practices for Sustainable Development ACEPS: 251- 259, Sri Lanka, 2012.

[65] Li, B. - Ke, G. - Zhou, M. (2011): Influence of manufactured sand characteristics on strength and abrasion resistance of pavement cement concrete, Construction and Building Materials, 25: 3849 - 3853 , 2011. https://doi.org/10.1016/j.conbuildmat.2011.04.004

[66] Wakchaure, M. R. - Shaikh, A. P. - Gite, B. E. (2012): Effect of types of fine aggregate on mechanical properties of cement concrete, International Journal of Modern Engineering Research, Vol. 2 (5): 3723 - 3726, 2012,

[67] Luo, F. J. - He, L. - Duan, W. H. - Zhao, X. L. - Collins, F. (2013): Effect of very fines particles on workability and strength of concrete made with dune sand, Construction and Building Materials, 47: 131 - 137, 2013. https://doi.org/10.1016/j.conbuildmat.2013.05.005
[68] Bellanger, M. - Chaouch, M. (1996): Interaction of binder-aggregate, Influence on mechanical properties of mortars and concretes, Mines and quarries, Mineral industry, 81-83, 1996. (in French)

[69] Bachiorrini, A. (1985): Physical and chemical interaction of monocalcic aluminate and carbonates during the hydration reaction, $\mathrm{PhD}$ thesis, University of Lyon I, p. 215, 1985 (in French)

[70] Husson, S. (1991): Physical-chemical and mechanical study of cementfillers interactions, application on mortars, $\mathrm{PhD}$ thesis, INP Grenoble and ENS of Mines Saint-Etienne, p. 139, 1991 (in French)

[71] Bentur, A. - Odler, I. (1996): Development and nature of interfacial microstructure. Interfacial transition zone in concrete, Ed. by Maso, J.C., RILEM Report 11, E \& FN Spon, London, 19 - 44, 1996.

[72] Bellanger, M. - Chaouch, M. - Homand, F. (1996): Mechanical behavior of mortars and concrete based limestone, Mines and quarries, Mineral industry, 57 - 61, 1996 (in French)

Ref:

Benabed, Benchaa: Effect of combined use of crushed sand and Algerian desert dune sand on fresh properties and strength of selfcompacting concrete Épitőanyag - Journal of Silicate Based and Composite Materials, Vol. 70, No. 5 (2018), 155-167. p https://doi.org/10.14382/epitoanyag-jsbcm.2018.29

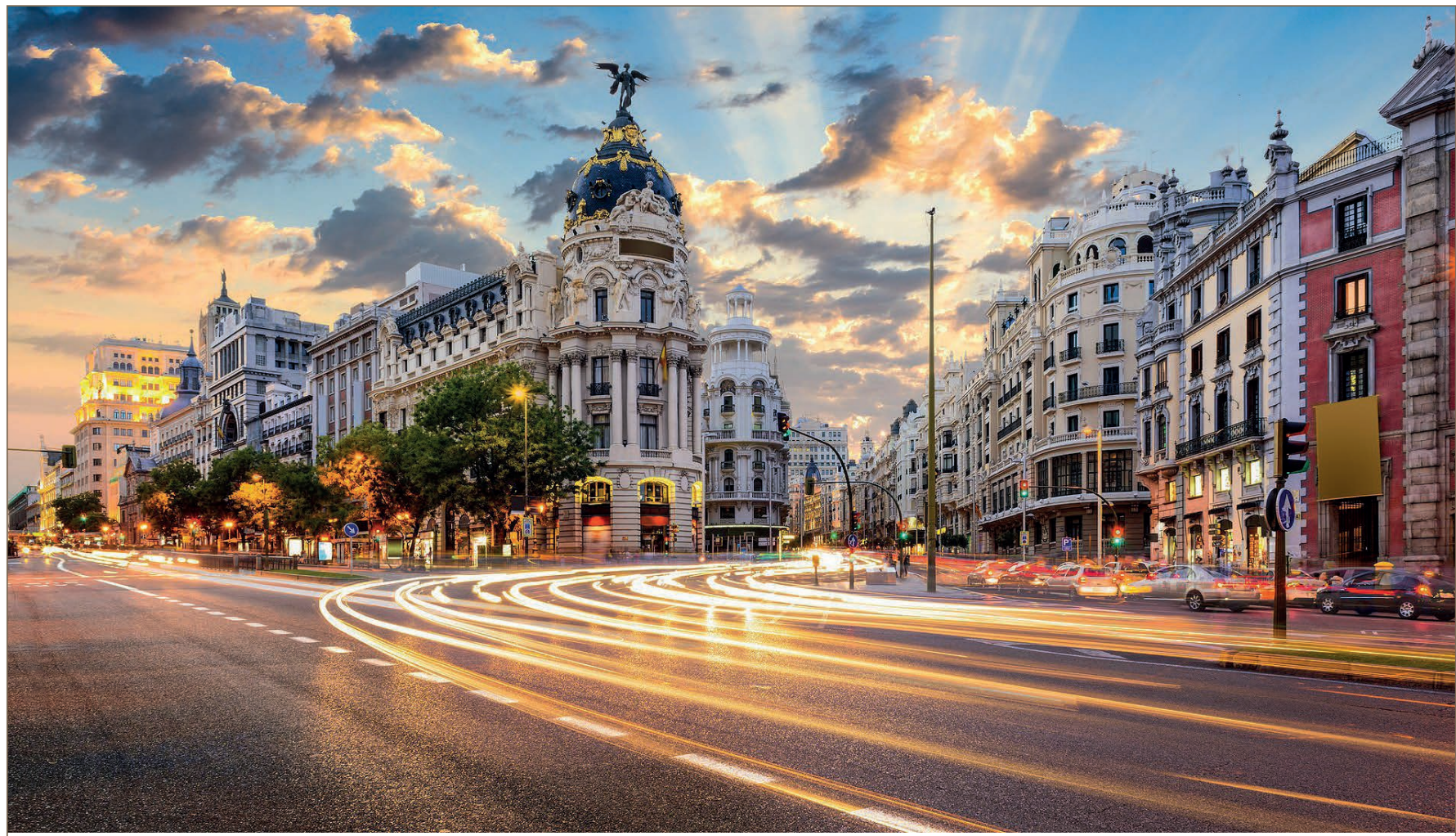

\section{Slag \& AshTrade Europe 2019}

March 28 - 29, 2019| Madrid, Spain |

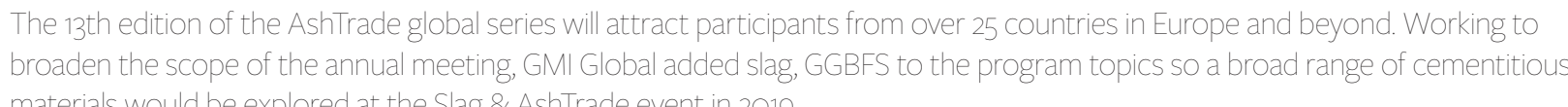

